Guénette M.-F. (2021). Insights into technical translation course design. Current Trends in Translation Teaching and Learning E, 8, 196 - 234. https://doi.org/10.51287/cttle20217

\title{
INSIGHTS INTO TECHNICAL TRANSLATION COURSE DESIGN
}

\author{
Marie-France Guénette
}

Université Laval

\begin{abstract}
This article offers theoretical and pragmatic insights into the nature of technical translation course design. In so doing, I first provide a definition of specialized translation based on a survey of the literature in this field, conducted collaboratively with a research assistant. Then, I present a comparative table sourcing how technical translation has been taught, as a university course, across Canadian higher education institutions. Following this, I offer a rationale for student-oriented ways of teaching this course, all the while giving concrete steps to coexplore novel topics with undergraduate and graduate students. Finally, I generate a series of considerations and questions for further inquiry into the instruction of technical translation in Canada and worldwide.
\end{abstract}

Keywords: technical translation, specialized translation, English-French translation, translation pedagogy, course design

\section{INTRODUCTION}

As I prepared my undergraduate and graduate courses in technical translation in the spring and 
Guénette M.-F. (2021). Insights into technical translation course design. Current Trends in Translation Teaching and Learning E, 8, 196 - 234. https://doi.org/10.51287/cttle20217

summer of 2020, I was struck by the incongruities in the resources available to teachers and students. The more I researched works published in both French and English, the less I understood the field in which I was to train students. My frustration increased as the weeks went on, for I was battling questions so essential they paralyzed my course design: what is technical translation, and how are we supposed to teach it? In this article, I address a few recurring issues in the pedagogy of technical translation surrounding the material available to educators and the features of the field. After presenting an overview of the data collection methodology for this course design, I provide answers to the following questions: 1) What is technical translation: how is it defined in published literature, and what does it encompass? 2) Why is technical translation taught in a separate course in translation programs, and what topics should be covered within this course? My aim is to provide an overview of existing definitions and resources available for teaching technical translation, and ultimately offer insights into course design. To do so, I draw on my experience as a professional translator and early career scholar of translation studies preparing and teaching both an undergraduate and a graduate course on technical translation using resources published in English and French. The inherent limitations to my approach are the time 
Guénette M.-F. (2021). Insights into technical translation course design. Current Trends in Translation Teaching and Learning E, 8, 196 - 234. https://doi.org/10.51287/cttle20217

constraint for course design and delivery, as well as the two languages mastered by my students.

\section{CONTEXT}

My course preparation began with an initial foray into existing publications, during which I created a list of published resources. I was granted a 27-hour teaching assistant contract, which I offered to an M.A. student from the Department of Languages, Linguistics and Translation at Université Laval. Though the student was not enrolled in a translation program, he stated that he was bilingual and willing to do the requested research. I provided him with a working definition of technical translation from the website of Technitrad, a translation agency specializing in technical translation located in the Greater Montreal Area (Canada):

A technical translation is a type of specialized translation involving the translation of documents produced by technical writers, or more specifically, texts that relate to technological subject areas or texts that deal with the practical application of scientific and technological information. ${ }^{1}$ (Technitrad, 2021)

${ }^{1}$ Since the student was given only the French version of this definition, as published on the Technitrad website at the time, I prefer to provide it to readers as well: "La traduction technique est une variante de traduction spécialisée qui implique la traduction de documentation technique, ou plus spécifiquement, de textes qui traitent de sujets provenant du domaine technologique ou qui portent 
Guénette M.-F. (2021). Insights into technical translation course design. Current Trends in Translation Teaching and Learning E, 8, 196 - 234. https://doi.org/10.51287/cttle20217

I instructed the student to search for French and English peer-reviewed publications published since 1970 that were available through our university library catalogue. My decision to include publications from 1970 onwards was based on my knowledge of translation studies, since prior to this date the field was not considered distinct from applied linguistics. As such, publications predating the "creation" of translation studies as a field of research distinct from linguistics tend to lean towards comparative stylistic analysis. To ensure we documented peer-reviewed articles on the topic, I also suggested that the student explore a series of translation studies journals, notably JosTrans, META: Translator's Journal, TTR: Translation, Terminology and Writing, Target, Babel, Circuit (magazine of the Ordre des traducteurs, terminologues et interprètes agréés du Québec), and The ATA Chronicle. Knowing the specialized nature of the field, I also recommended that he include any publications addressing the terminological characteristics and challenges of technical translation.

After eight hours of research, the student informed me that his results using the keywords "traduction

sur l'application pratique d'information scientifique et technologique" (Technitrad 2020). 
Guénette M.-F. (2021). Insights into technical translation course design. Current Trends in Translation Teaching and Learning E, 8, 196 - 234. https://doi.org/10.51287/cttle20217

technique" (technical translation in French) were disappointing. He had found publications addressing various "specialized" translation fields, like legal translation, and some on the topic of technology, but little else. He reiterated that he was trying to stay as close as possible to the guiding definition of technical translation I had provided. After a discussion, we agreed that he would continue to expand the definition to include such topics as civil and military aviation. I offered links to the International Civil Aviation Organization (ICAO), Transport Canada's website on civil aviation, the Royal Canadian Air Force and the Aerospace Industries Association of Canada. The student saved links and documents in a shared cloud folder, and I used these resources to complement my own research.

I further benefitted from access to syllabi from previous technical translation courses taught in the department. Drawing on the resources identified by the student, the existing syllabi, and books I had purchased ahead of my course design, I reviewed all the literature and selected the texts my future students would read, as well as the themes I was likely to explore in my courses. As translation courses in my department are mainly given in French, I favoured publications in this language, especially at the undergraduate level. I was attentive to the location of publication and the origins of the author, as some 
Guénette M.-F. (2021). Insights into technical translation course design. Current Trends in Translation Teaching and Learning E, 8, 196 - 234. https://doi.org/10.51287/cttle20217

works cater specifically to the French Canadian translation market. As there are few experts in the field who publish in French and English, I included a wide range of resources beyond the specific characteristics of the Canadian market.

\section{CORE ISSUES RELATED TO TECHNICAL TRANSLATION AND ITS TEACHING RESOURCES}

\subsection{What is technical translation: how is it defined in published literature and what does it encompass?}

Once the literature review was complete, I began exploring the resources with a focus on published books about the field, before turning to peerreviewed articles. Starting with English-language books, I quickly came across a significant problem: definitions of the field were inconsistent. In his 2006 book, Jody Byrne initially defined technical translation through a process of elimination by tackling misconceptions about the field. Following an informative dismantling of common perceptions, Byrne contrasted technical and scientific translation, and argued that "Technical translation [...] can be characterised at a basic level on the basis of: 1 . subject matter 2. type of language 3. purpose" (Byrne, 2006, p. 8). More insightful, perhaps, was his 
Guénette M.-F. (2021). Insights into technical translation course design. Current Trends in Translation Teaching and Learning E, 8, 196 - 234. https://doi.org/10.51287/cttle20217

suggestion of the aim of technical translation: "to ensure that all of the relevant information is indeed conveyed but also that it is conveyed in such a way that the readers can use the information easily, properly and effectively" (Byrne, 2006, p. 10). In his more recent book, Byrne again tackled the distinction between technical and scientific texts, arguing this time that "while a technical text is designed to convey information as clearly and effectively as possible, a scientific text will discuss, analyze and synthesize information with a view to explaining ideas, proposing new theories or evaluating methods" (Byrne, 2012, p. 2, author's emphasis).

Similarly, Maeve Olohan's 2015 book on Scientific and Technical Translation brought these two fields together and suggested a definition along the same lines. Olohan's assumption that the word "technical" in technical translation designates "technology" led her to group scientific and technical translation together: "we can adopt the convenience of grouping science and technology together, while recognizing that the nature of the domains and the dynamic relationships between them can be understood in different ways" (Olohan, 2015, p. 7). In so doing, she chose to "focus on the ways in which texts and language are used to perform specific communicative functions in technical and scientific contexts" (Olohan, 2015, p. 7). I do not seek here to challenge 
Guénette M.-F. (2021). Insights into technical translation course design. Current Trends in Translation Teaching and Learning E, 8, 196 - 234. https://doi.org/10.51287/cttle20217

this inclusive approach, though for my objective of teaching a course exclusively on technical translation in an institution that also offers courses on scientific translation, I was forced to seek more discriminating materials.

There were just as few books on technical translation in French, and they were more dated than those published in English. In my attempt to find a manual that would fit my needs, I looked to Claude Bédard's La traduction technique (1986a), which comes with an instructor's manual and answer key, and to Christine Durieux's Fondement didactique de la traduction technique (2010), originally published in $1990^{2}$. In contrast to the English-language books, Bédard immediately distances technical translation from its scientific counterpart. On the very first page of his manual, he states: "This book covers only technical translation, excluding fields such as scientific translation" (Bédard, 1986a, p. 1) ${ }^{3}$. By positioning his work as opposite to scientific translation, Bédard challenges the similarities put

${ }^{2}$ It is to be noted that Jean Maillot's (1981) La traduction scientifique et technique is in circulation, though out of print. At the time of writing this article, I had purchased a used copy on Abebooks. I did not, however, consider using this manual for my course, due to the restricted availability.

${ }^{3}$ All quoted French text in this article was translated by Wynne Miller, Valentine Patin, and me. 
Guénette M.-F. (2021). Insights into technical translation course design. Current Trends in Translation Teaching and Learning E, 8, 196 - 234. https://doi.org/10.51287/cttle20217

forth by Byrne and Olohan (as defined above). In contrast, in her pedagogical guide, Durieux gives a broad definition of technical translation as the translation of "technical," "technological," and "scientific" texts $(2010$, p. 23$) .{ }^{4}$ The statement that follows this definition echoes the controversial nature of technical translation for, according to Durieux, "one could argue for hours about the limitations of the technical nature of a text" (Durieux, 2010, p. 23). She extrapolates this statement further, citing that she considers texts of a technical nature to be those that cover technical, technological and scientific subjects, as is commonly understood (p. 24). ${ }^{5}$

In my attempt to establish a clear definition of the field for my students, I turned to an article astutely titled Qu'est-ce que "texte technique" veut dire? (that is, What does "technical text" mean?), in which N'Zafio (1996) tackles the similarities and

4 "It is actually the translation of technical, technological or scientific texts" (Durieux, 2010, p. 23).

5 "In this study, we consider texts on technical, technological and scientific topics to be technical texts, in the accepted sense of the term. As it appears in Le Grand Robert, 'Technical' is defined as 'adjective. 1. (As opposed to common, general, unspecialized). Belonging to a specific specialized field of activity or knowledge.' This meaning, which comes from social consensus, will be our basis when defining technical texts" (Durieux, 2010, p. 24). 
Guénette M.-F. (2021). Insights into technical translation course design. Current Trends in Translation Teaching and Learning E, 8, 196 - 234. https://doi.org/10.51287/cttle20217

differences between "technical" and "scientific" texts to bring clarity to the field. In the article, he first reviews definitions of the adjective "technical" in the fields of translation studies and terminology, including i) "technical" within the meaning of specialized, specific to a given field of activity of knowledge; ii) "technical" implying technology; and iii) "technical" as a synonym of scientific (N'Zafio, 1996, p. 46). In a different article (see Zafio, 1996), the author presents a more detailed overview of the etymological history of the adjective "technical" for readers to better grasp the complex nature of the meanings ascribed to the term, though this is more oriented to terminology than needed here. Following this overview of common meanings of the adjective "technical," he postulates that both technical and scientific texts include specialized content. What distinguishes them, according to N'Zafio (1996), is that technical texts are oriented towards practice (p. 56), whereas scientific texts are oriented towards knowledge for the sake of knowledge (p. 58). ${ }^{6}$

6 "Thus, saying a text is technical is to claim two things: that its content is specialized and that it is oriented towards practice" (N'Zafio, 1996, p. 56). "Saying a text is scientific is to observe two facts: that its content is specialized and that it is oriented towards knowledge for the sake of knowledge" (N'Zafio, 1996, p. 58). 
Guénette M.-F. (2021). Insights into technical translation course design. Current Trends in Translation Teaching and Learning E, 8, 196 - 234. https://doi.org/10.51287/cttle20217

I was thus faced with the difficult task of guiding students into a field that had so many grey, yet overlapping, zones that its very definition was challenged by each scholar who researched it. Going back to the definition published on the Technitrad website, it became clear that this interpretation of the field was more succinct than any other definition I had come across in academic publications.

A technical translation is a type of specialized translation involving the translation of documents produced by technical writers, or more specifically, texts that relate to technological subject areas or texts that deal with the practical application of scientific and technological information. (Technitrad, 2021)

With this definition, we validate the specialized nature of this type of translation. We further learn of a connection with technical writers, which was not specifically mentioned in the other definitions. We see the links to technology as well as pragmatic applications of science and technology. In my efforts to provide students with a pedagogically sound definition of technical translation, I had somehow overlooked the definition that guided my research assistant and me in our initial forays into the field. After reviewing books and articles published in French and English, I chose to rely on the wording by Technitrad, a leader in the Canadian technical translation industry, as the holistic and well- 
Guénette M.-F. (2021). Insights into technical translation course design. Current Trends in Translation Teaching and Learning E, 8, 196 - 234. https://doi.org/10.51287/cttle20217

articulated definition for my courses on technical translation. Maintaining a logic of continuous improvement, I welcome both similar and contrasting definitions from publications in other languages as part of a healthy debate on the boundaries of this field of specialized translation.

\subsection{Why is technical translation taught in a separate course in translation programs, and what topics should be covered within this course?}

Throughout my preparation, I wondered what made technical translation so unique that it required students to train in a designated course. As I delved into the literature and practical aspects of the field, I asked myself why technical translation, as a branch of specialized translation, should be taught as a distinct 45-hour, 3-credit university course. To complement the findings provided in publications, I surveyed the descriptions for English to French technical translation courses taught at Canadian universities, and noted most institutions offer a specific course on this specialty. For a detailed comparison, I compiled the descriptions available online for courses in technical translation from English to French in universities across Canada (see Table 1). 
Guénette M.-F. (2021). Insights into technical translation course design. Current Trends in Translation Teaching and

Learning E, 8, 196 - 234. https://doi.org/10.51287/cttle20217

Table 1. Descriptions of English to French technical translation courses taught in Canadian universities (compiled in March 2021), translated into English for the benefit of this article.

\begin{tabular}{|c|c|}
\hline 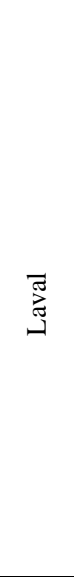 & $\begin{array}{l}\text { TRD2152-Technical Translation } \\
\text { Course goals: application of translation and terminology theory to } \\
\text { technical domains; study of the different types of challenges that can } \\
\text { be encountered when translating technical texts in general, and more } \\
\text { specifically, in the field of computer science; study of the } \\
\text { characteristics of technical language; development of methods for the } \\
\text { analysis and translation of technical texts. Content: definition of the } \\
\text { field of technical translation; classification of technical texts; } \\
\text { characteristics of technical writing in English and French; principal } \\
\text { sources of documentation; translation of texts belonging to different } \\
\text { technical fields. } \\
\text { TRD7007 - Technical Translation } \\
\text { Course goals: study of the theory and practice of technical translation; } \\
\text { analysis of the characteristics of technical discourse; critical review } \\
\text { of the primary approaches to technical translation. Content: study of } \\
\text { pieces and articles on technical language and translation; critical } \\
\text { examination of terminology and informational resources; translation } \\
\text { of technical texts. }\end{array}$ \\
\hline 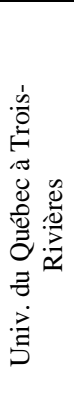 & $\begin{array}{l}\text { TRA1078 - Technical Translation* } \\
\text { Study of key resources for technical translation. Acquisition of } \\
\text { methods for translating texts in the field of mechanics. Application of } \\
\text { the skills acquired during the class. } \\
\text { TRA1072 - Introduction to the technical domain in translation. Study } \\
\text { of the methodology of technical translation. Integration of technical } \\
\text { language in French in translation of texts on mechanics. Study of } \\
\text { tools for technical translation. } \\
\text { TRA6016 - Technical writing and translation** } \\
\text { Study of the basics of electricity and electrical engineering. } \\
\text { Knowledge of these subjects is necessary to produce faithful and } \\
\text { idiomatic translations of texts on electrical engineering. Translation } \\
\text { of various specialized texts. }\end{array}$ \\
\hline
\end{tabular}




\section{Guénette M.-F. (2021). Insights into technical translation course design. Current Trends in Translation Teaching and \\ Learning E, 8, 196 - 234. https://doi.org/10.51287/cttle20217}

\begin{tabular}{|c|c|}
\hline 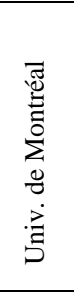 & $\begin{array}{l}\text { TRA } 2515 \text { - Technical Translation* } \\
\text { Analysis and translation of different types of technical texts while } \\
\text { factoring in notional systems, terminological systems, and } \\
\text { phraseological systems. Development of an applied approach to } \\
\text { specialized knowledge. } \\
\text { TRA } 6105 \text { - Technical Translation } \\
\text { Simulation of the professional translation of technical texts in a } \\
\text { controlled environment. Review of the approach taken; optimization } \\
\text { of this approach to increase efficiency while maintaining quality. }\end{array}$ \\
\hline 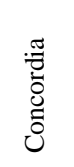 & $\begin{array}{l}\text { FTRA } 515 \text { - Technical and Scientific Translation } \\
\text { English to French. Introduction to multiple challenges in translation } \\
\text { of scientific and technical language. The course is split into two or } \\
\text { three sections, each exploring a different specialized field of } \\
\text { translation. }\end{array}$ \\
\hline 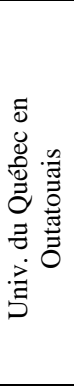 & $\begin{array}{l}\text { TRA } 1383 \text { - Technical and Scientific Translation } \\
\text { English to French. Acquaintance with the practice and requirements } \\
\text { of technical and scientific translation through an approach which } \\
\text { integrates knowledge acquired in previous translation courses as well } \\
\text { as the principles of terminological research and information retrieval. } \\
\text { Content: Specific features of technical and scientific language. } \\
\text { Principles and requirements of technical and scientific translation. } \\
\text { Acquisition of basic theory and linguistic knowledge in specialized } \\
\text { fields by utilizing relevant resources. Translation of a range of texts } \\
\text { in several specialized fields (popular texts, educational material, } \\
\text { instructional notices and manuals, articles, etc.) with different target } \\
\text { audiences. The fields studied can vary from year to year. }\end{array}$ \\
\hline $\begin{array}{l}\overline{0} \\
\dot{0} \\
\Sigma\end{array}$ & $\begin{array}{l}\text { CCTR } 453 \text { Technical Translation: Information Technology } \\
\text { Technical translation from English to French, focusing on IT-related } \\
\text { products. Overview of key concepts which include localization, } \\
\text { internationalization and globalization. Introduction to, and study of, } \\
\text { translation problems specific to these texts, as well as the various } \\
\text { strategies, appropriate resources and tools used to mitigate them. } \\
\text { Practice with software localization, in particular, user interfaces, user } \\
\text { manuals and online help, as well as other texts related to computer } \\
\text { applications in various industries. } 1.5 \mathrm{cr} \text {. }\end{array}$ \\
\hline
\end{tabular}


Guénette M.-F. (2021). Insights into technical translation course design. Current Trends in Translation Teaching and Learning E, 8, 196 - 234. https://doi.org/10.51287/cttle20217

\begin{tabular}{|c|c|}
\hline 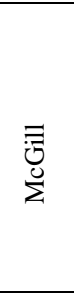 & $\begin{array}{l}\text { CCTR } 455 \text { Technical Translation: Transportation } \\
\text { Technical translation from English to French focusing on } \\
\text { transportation. Emphasis on terminology, phraseology and the inner } \\
\text { workings of mechanical engineering, civil engineering and } \\
\text { architecture. Study of the translation problems specific to these texts, } \\
\text { as well as the various strategies, appropriate resources and tools used } \\
\text { to mitigate them. Translation exercises will focus on technical texts } \\
\text { related to machinery, machine tools and vehicles, as well as physical } \\
\text { structures (bridges, tunnels, subways, ports and airports). } 1.5 \mathrm{cr} \text {. }\end{array}$ \\
\hline 胥 & $\begin{array}{l}\text { TRA3544 and TRA4533 - Technical Translation } \\
\text { English to French. Introduction to technical translation and } \\
\text { fundamental technical concepts. Informational research on chosen } \\
\text { topics. Translation of printed or digital texts in specialized technical } \\
\text { fields. In-depth documentation of the fields studied. }\end{array}$ \\
\hline 峞若 & $\begin{array}{l}\text { TRAD } 4411 \text { - Technical and scientific translation } \\
\text { Review and application of the principles of translation into French to } \\
\text { scientific and technical texts. Establishment of informational and } \\
\text { terminological records in those fields. }\end{array}$ \\
\hline 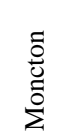 & $\begin{array}{l}\text { TRAD } 4525 \text { - Technical Translation } \\
\text { Study of the approach unique to technical translation. Exploration of } \\
\text { the basic principles in at least one specialized field. Translating } \\
\text { technical texts into French. }\end{array}$ \\
\hline
\end{tabular}

Looking to the course descriptions compiled in Table 1, a few observations can be made regarding technical translation pedagogy in Canadian institutions. First, two institutions have mandatory thematic courses on the language and vocabulary of the technical field as prerequisites for technical translation; this is the case for UQTR's TRA1078 and Université de Montréal's TRA2515. Second, two institutions provide specific training on technical writing within a translation program; such is the case for UQTR's TRA6006 shown above, and UQO's 
Guénette M.-F. (2021). Insights into technical translation course design. Current Trends in Translation Teaching and Learning E, 8, 196 - 234. https://doi.org/10.51287/cttle20217

course on technical and scientific writing (ECR1223). York University's Glendon College does not teach technical translation, but includes Techniques in Business and Technical Writing I \& II. Third, some universities across Canada offer English to French translation programs at the undergraduate and postgraduate levels, as part of their School of Continuing Studies, such as McGill University. In addition to the courses referenced above, McGill's program includes a 1.5 -credit specialized course in technical translation from French to English on energy and natural resources (CCTR 465). Another trend I wish to draw attention to here is the decision of certain institutions to combine technical and scientific translation within one course; this is the case at Concordia, UQO and Saint-Boniface. As one reviewer noted, the decision to combine technical and scientific translation into one course might be due to the specific expertise of given course lecturers and professors. However, having seen how frequently technical and scientific translation are defined as complementary (see section 3.1), it is not surprising that these fields were merged into a single course. Another potential explanation is the necessity for institutions to consolidate various topics under one course due to the vast array of skills that need to be imparted to students to prepare them for the translation profession. 
Guénette M.-F. (2021). Insights into technical translation course design. Current Trends in Translation Teaching and Learning E, 8, 196 - 234. https://doi.org/10.51287/cttle20217

In the literature, experts recommend various approaches to teaching technical translation. Bédard (1986a), for instance, claims the technical translator must attend several courses in various fields to acquire the necessary expertise prior to translating a technical text. Durieux (1990b) argues instead that the translator need only acquire the knowledge that will allow them to grasp the necessary concepts for the task at hand. This idea is debated in academic publications, with Durieux blatantly criticising Bédard's approach:

Contrary to what Claude Bédard believes [...], technical translators do not need to take formal courses in a variety of fields. In fact, to translate any given text, translators merely need to seek the necessary information in each discipline to form their own pyramid, simply responding to immediate need. (Durieux, 1990b, p. 671)

I tend to agree with Durieux because of the extensive variety of fields under the umbrella of technical translation, whereas I find Bédard's recommendation to acquire a range of targeted knowledge and expertise to be challenging. Indeed, no translator could ever know everything before they set out to translate a text. This meant there would be a limit to what my students could learn in the context of a single course. 
Guénette M.-F. (2021). Insights into technical translation course design. Current Trends in Translation Teaching and Learning E, 8, 196 - 234. https://doi.org/10.51287/cttle20217

Another problematic aspect in Bédard's manual was the recommended pedagogical strategy that converged around a single field of technical studies:

Traditionally, a technical translation course covers several fields [...]. The drawback of this approach is that most of the time is spent on introduction to the fields in question, which results in a surface-level understanding. Our approach favors an intellectual method. Therefore, we find it preferable to study only one domain. (Bédard, 1987, p. 6, author's emphasis)

Bédard is not opposed to the idea that technical translation be taught using a variety of fields, as he adds that "it is possible to instill some principles of technical translation without using specialized material as a medium; for example, by using slightly technical instruction manuals that still call for an approach that is 'technical' in essence" (1987, p. 6-7, author's emphasis $)^{7}$. Despite this openness to a wider skill set, his manual concentrates on electronic engineering, which is logical when we consider that this is his own field of expertise. In contrast, Durieux (2010) describes a pedagogical approach centered on a progressive learning of technical translation

7 “ $[I] 1$ est possible d'inculquer certains principes de traduction technique sans avoir recours au médium d'une matière spécialisée; par exemple en utilisant des textes de mode d'emploi faiblement technique, mais qui font appel à une démarche essentiellement 'technique"” (1987, p. 6-7, author's emphasis). 
Guénette M.-F. (2021). Insights into technical translation course design. Current Trends in Translation Teaching and Learning E, 8, 196 - 234. https://doi.org/10.51287/cttle20217

strategies through a variety of texts chosen for their level of difficulty rather than their similar subject matter.

These contrasting views on technical translation pedagogy left me wondering what decisions would guide my own course design. Bédard argues that choosing a single field is not synonymous with monotony for students, and that whatever the student's level of interest (or lack thereof) for the chosen topic, it is important to insist on the fact that the topic serves only as a pretext for learning principles that will later be applicable to any specialty (1987, p. 7). Due to my limited knowledge in technical fields, I considered choosing a specialized topic (i.e., electromechanics, or civil and military aviation $)^{8}$ and learning it alongside my students throughout the term. Despite Bédard's reassurance, the prospect of imposing a topic which would bore my students led me to outline my course and leave room for student input in the syllabus. In the third course, customary to common studentcentered Freiran pedagogies, I offered my graduate students the choice between i) collectively choosing

${ }^{8}$ For electromechanics, I would have relied on Bédard (1986a) and (1987), as well as Senécal, Bédard, et al. (1987). Had I chosen civil and military aviation, I would have made Senécal (2012) a mandatory purchase for the course, and chosen texts aligned with the information provided in the book. 
Guénette M.-F. (2021). Insights into technical translation course design. Current Trends in Translation Teaching and Learning E, 8, 196 - 234. https://doi.org/10.51287/cttle20217

a topic that we would analyze throughout the term, and ii) exploring a variety of technical fields by choosing a different one each week. I warned them that changing fields weekly would entail more documentary research, a fact Bédard makes plain in a section titled "Épargner à l'étudiant les efforts documentaires superflus" (1987, p. 9), which roughly translates as Sparing students unnecessary documentation efforts. Nevertheless, the vote for variety was unanimous, for students feared rapid loss of interest should we repeatedly confront the challenges of a single field.

Together, we resolved to explore diverse topics, and chose a series of subjects, ranging from nuclear energy and marine current power to technological inventions and used tire recycling. Guided by Bédard's (1987) learning objectives, I invited students to embrace the uncomfortable feeling of translating something they barely understood. After each exercise, they were grateful for having explored the topic, but more importantly, they recognized that they were more skilled than they might have initially thought. In many ways, they were surprised by the benefits of researching concepts that were novel to them. And though the level of expertise required to achieve a satisfactory result varied from one translation exercise to the next, the main skills acquired remained the same. Students gained 
Guénette M.-F. (2021). Insights into technical translation course design. Current Trends in Translation Teaching and Learning E, 8, 196 - 234. https://doi.org/10.51287/cttle20217

confidence in their research and translation abilities, and cultivated intellectual curiosity in fields they would not have necessarily explored otherwise or elsewhere.

After reviewing the literature and Canadian practices in technical translation pedagogy, I argue that although many general and even specialized translation courses focus chiefly on learning outcomes related to practical language transfer skills, technical translation requires the acquisition of a distinct skill set. As for the matter of what topics should be covered within a technical translation course, the answer varies according to the skills and knowledge of the instructor. In the same vein as Bédard's (1987) argument about electromechanics, René Tondji-Simen published an article in 2005 detailing what he considered essential concepts for technical and scientific translators. In my opinion, there is no absolute requirement, because students can benefit equally from a specialized course on electromechanics or, for example, one on information technology.

\subsection{Transposing the knowledge from the field into pragmatic considerations for technical translation course design at the graduate level}


Guénette M.-F. (2021). Insights into technical translation course design. Current Trends in Translation Teaching and Learning E, 8, 196 - 234. https://doi.org/10.51287/cttle20217

With these insights in mind, I established the syllabus for a 14-week, 3-credit graduate-level course on technical translation (see Appendix 1 for the reading list). In this section, I will specify which readings and exercises were chosen and what purpose they served. The topics for each week were modeled after Bédard's (1986a) learning objectives, and adapted to correspond to the assigned readings. I divided the contents of the course into four modules, ranging from a basic introduction of the subspecialty to concrete applications and strategies for marketing professional services. The first module, titled The specificity of technical translation, was meant to reproduce the chaos and confusion I had initially felt when designing the course. In this structured learning environment, I accompanied students through a series of readings meant to help them understand the defining features of technical translation. During week 1, students read Hugo Marquant's Formation à la traduction technique, from which they learned that "techniques" are "methodical procedures based on scientific knowledge and used for production" (Marquant, 2005, p. 129). They also discovered that technical works relate to three wider areas of production: i) areas of human activity; ii) exact sciences, technical sciences and techniques; and iii) general technology, applied technology, and industrial interface. The reading assigned for the second week clarified the distinctions between 
Guénette M.-F. (2021). Insights into technical translation course design. Current Trends in Translation Teaching and Learning E, 8, 196 - 234. https://doi.org/10.51287/cttle20217

technical and scientific translation (N'Zafio, 1996). Although both are considered specialized, the former has a practical orientation, and the latter is intended to disseminate knowledge. At this point in the course, students were still unable to gauge the scope of the field of technical translation. We nevertheless began translating technical texts, with a first practical inclass assignment on electricity.

At the third week, students read the introduction to a practical guide on translating for the military and aviation industries. In the article, André Senécal (2012) shared a series of essential qualities of technical translators which, as my students were quick to notice, apply to all professional translators. According to Senécal (2012), a technical translator should have an extended passive knowledge of the source language, demonstrate fluency in the target language, be methodical, show strong intellectual curiosity, know the fundamentals of terminology, master the theory and practice of translation, and have strong critical thinking skills. Perhaps what most struck my students was Senécal's insistence that translators should stay humble, regardless of their expertise, and retain a sense of wonder throughout their career. As a practical application, we translated a text from the construction industry on asbestos management. 
Guénette M.-F. (2021). Insights into technical translation course design. Current Trends in Translation Teaching and Learning E, 8, 196 - 234. https://doi.org/10.51287/cttle20217

The fourth week marked the turn towards a more indepth, practical understanding of technical translation. Students read Christine Durieux's (1990b) La recherche documentaire en traduction technique, in which the author stresses the importance of understanding a text prior to translating it. Durieux makes plain the fact that all translators, regardless of their level of expertise, need to conduct documentary research when translating a technical text. The amount of time required will vary depending on whether translators are well versed on the subject of the source text. Durieux argued in her work that documentary research was timeconsuming for translators who did not master a given topic, and seeing as I had chosen to introduce students to a variety of technical subjects throughout the course, I had to establish some parameters to ensure they did not overexert themselves every week. Thus, from this point on in the term, I began ascribing temporal limitations to assigned translations because students would otherwise spend hours reading accompanying documentation prior to translating. No amount of reading ever gave them the sense of accomplishment and satisfaction they hoped to attain-instead, it fuelled their anxiety and uncertainty. Therefore, to reverse this trend, I assigned a 400-word translation on the topic of tidal hydroelectric energy with a structured 60-90-minute timeframe. This intentionally difficult assignment 
Guénette M.-F. (2021). Insights into technical translation course design. Current Trends in Translation Teaching and Learning E, 8, 196 - 234. https://doi.org/10.51287/cttle20217

was designed to help students accept the instability and anxiety caused by technical texts. I clarified they would likely feel uncomfortable when faced with a technical text, and that the best use of their time in this course was to learn to accept the uncertainty and rise above anxiety-inducing tasks. Such skills, I argued, would be useful for translation tests and job interviews throughout their careers.

Once students had grasped the vastness of technical translation in this introductory course, they were ready for the second module in which they would learn concrete strategies to help them overcome the difficulties of technical texts. As I had challenged students with weekly exercises of varying technical difficulty, they were regularly confronted with new concepts, vocabulary, and areas of expertise. The second module combined three main principles that would help them address these challenges: the use of rapid documentary research, the potential of context, and the importance of plain language. Each week had an assigned reading that provided an overview of the strategy. As part of their evaluations, students prepared an oral presentation (recorded due to the pandemic) in which they presented an overview of one of the readings. These presentations began on week 5, with the start of the second module, once students had sufficient knowledge of the field to position themselves and their peers within the wider 
Guénette M.-F. (2021). Insights into technical translation course design. Current Trends in Translation Teaching and Learning E, 8, 196 - 234. https://doi.org/10.51287/cttle20217

context of the specialty. From this point on, students would read the assigned article, and watch the recorded presentation prepared by one of their peers. If given articles had not been selected for a student presentation, I would prepare an overview and critical analysis myself. Thus, at week 5, we read Lagarde \& Gile's (2011) article on the challenges of documentary research, and translated an excerpt on radioactive waste derived from nuclear energy. The following week, we read Bédard (1986b) to learn how to further exploit the context provided within the source text, and translated a text on new technologies for recycling tires.

With a strong knowledge of the field and an understanding of which strategies to employ when faced with a complex technical text, students were prepared to train in relevant writing styles. During the $8^{\text {th }}$ week of the course, I taught them to use plain language - sometimes referenced as plain English or langage clair in French-in their technical translations. We analysed examples from resources such as La langue claire et simple (meaning Clear and simple language, PWGSC, 2021) and How to write clearly (European Commission, 2011). The corresponding weekly reading, Translation and Technical Communication: Chicken or Egg? by Minacori and Veisblat (2010), drew students' attention to the intimate ties between technical 
Guénette M.-F. (2021). Insights into technical translation course design. Current Trends in Translation Teaching and Learning E, 8, 196 - 234. https://doi.org/10.51287/cttle20217

translation and technical writing. They further discovered which skills and competencies were required of experts in the field, and made connections to Senécal's (2012) qualities of technical translators. I created the weekly practical exercise from a workplace safety procedure manual for a restaurant in British Columbia. Though the text referred to unions and safety regulations, the writing style was clear and accessible, which made it a perfect text for the application of clear language writing strategies. With this assignment, students were reminded of the importance of writing for all readers, not only experts, and consequently chose accessible terminology and phrasing. As we discussed in class, many readers lack the necessary literacy skills to understand such technical texts, even though these very texts are written for their benefit in the case of workplace safety guidelines.

The third module, titled Practical applications, was another opportunity for students to acquire reading and writing skills relevant to technical translation, such as technical writing and clear writing for complex subjects. In acquiring these skills, students also learned to determine which of these forms of writing should be used in which circumstances, like in cases where technical vocabulary lacks precision. As such, during week 9, we read Ryan's (2011) article on controlled natural languages. Though the 
Guénette M.-F. (2021). Insights into technical translation course design. Current Trends in Translation Teaching and Learning E, 8, 196 - 234. https://doi.org/10.51287/cttle20217

limited timeframe only allowed us to cover the basics of controlled languages, we explored the European Commission's Interinstitutional Style (2011) and discussed the usefulness of such strategies. The assigned exercise was a short text on low-cost technology which employed terminology from technological innovation and information technology. Building on the basic knowledge of controlled languages and broad communication strategies, I devoted week 10 to expertise in communication for complex technical texts. The assigned reading was an article by Christine Durieux (1990a) on the issue of foisonnement, or the increase in word count through the process of technical translation. In it Durieux challenges translators to be concise and not seek to explain through paraphrase and bulky wording. Our practical exercise pertained to solar panels and energy efficiency, which most students enjoyed, given their general interest in environmental sciences and green energy.

The following week, we discussed the imperfection of technical vocabulary and the struggles of translating adequately despite problematic source texts. The accompanying readings were an intriguing article by Christine Durieux (2000b) in which the author draws parallels between literary and technical translation. We also read Minacori (2005) on the epistemological positioning of scientific and 
Guénette M.-F. (2021). Insights into technical translation course design. Current Trends in Translation Teaching and Learning E, 8, 196 - 234. https://doi.org/10.51287/cttle20217

technical translation, which helped students understand a larger scope of learning outcomes. Our weekly thematic student presentations introduced the class to the challenges of translating texts on geothermal energy and shipbuilding. The following class was devoted to the importance of recognizing the target audience, drawing on Dalügge-Momme's 2008 article on cultural aspects of technical translation. We discussed the challenges of localization and adapting content to specific readerships. Students presented their research on drones and the technical language of architecture.

The final module, titled Review of acquired skills and knowledge, tackled the connections between translation theory and technical translation, as well as a series of concrete approaches that translators-intraining can undertake to integrate into the workforce. Over the course of weeks 13 and 14, students read "Theory in technical translation", a section from Byrne's (2006) book on Technical Translation, and I encouraged debate on the clashes between professional translators and translation studies researchers. In class, we discussed questions like "What is the relevance of theorizing translation if such theories do not meet the needs of professional translators?" and "What use do you see for theory in your training to become a professional translator?" We also hosted a professional translator who worked 
Guénette M.-F. (2021). Insights into technical translation course design. Current Trends in Translation Teaching and Learning E, 8, 196 - 234. https://doi.org/10.51287/cttle20217

for over 10 years in technical fields such as information technology and notably translated technical documents. Students could ask questions on how one becomes a technical translator, or rather, how one can transition from translating general to more complex technical texts. Through a series of discussions on marketability, the guest speaker and I sought to help students learn how they could improve their skills while earning a salary. Students saw to what extent Senécal's (2012) depiction of technical translators as inquisitive and curious rang true in the profession. I ethnographically observed, however, that they had gained confidence throughout the course - though they had not become experts over one course, they were no longer afraid of technical texts. They knew that, should they wish to enter this area of the profession, they would hopefully find work and supportive colleagues and revisors to help them through their first forays.

\section{FINAL OBSERVATIONS}

The reflections put forth in this article derive from my preparation and delivery of courses on technical translation, using resources published in French and English. Throughout my course design and delivery, I noticed contradictory definitions and a strange assortment of pedagogical resources in technical translation. As indicated in section 3.1, the very 
Guénette M.-F. (2021). Insights into technical translation course design. Current Trends in Translation Teaching and Learning E, 8, 196 - 234. https://doi.org/10.51287/cttle20217

definition of technical translation is often debated. What is more, many publications are so outdated that they predate the Internet and recommend that students make time to "travel" to the library to find answers to their terminology or subject matter queries. I encourage scholars to view the issues highlighted in this article as an invitation to produce further pedagogical resources on technical translation for the English and French linguistic markets. There is an abundance of expert technical translators; what better way to improve translator training than to make their knowledge available across languages? After only a year of exploration and teaching in this field, I am certain of the need for specialists in technical translation to come together and publish special issues and edited volumes on recent advancements in the field. Any such publication could become a theoretical manual for students of technical translation.

And what of the job market in Canada for those with a freshly minted translation degree? As I frequently remind my students, they are professional translators in the making. They are the next generation of experts who will make advances in the field, and to do so, they must acquire expertise by furthering their learning in practical settings. For those teaching the next generation of professional translators, Durieux reminds us of the nature of the task at hand: 
Guénette M.-F. (2021). Insights into technical translation course design. Current Trends in Translation Teaching and Learning E, 8, 196 - 234. https://doi.org/10.51287/cttle20217

In a translation school, the teacher has a dual role: training students to execute translations, but also preparing them for professional life by raising awareness of the kinds of socio-professional problems they will likely encounter throughout their careers. (Durieux, 1990/2010, p. 114)

Indeed, we must not neglect our role in preparing students for the job market. A skilled technical translator is one who recognizes the abilities that employers require of them, which is why I added the article by Patricia Minacori and Lucy Veisblat (2010) on technical translation and communication, as well as the first chapter of André Senécal's (2012) book to the mandatory readings of my graduate course. Creating a setting that favors discussions on the skills and abilities of technical translators helps students position themselves in relation to their (soon-to-be) professional competition. It also allows for conversations on anxieties, insecurities, and imposter syndrome, which are endemic to classes of graduating students.

In conclusion, though one technical translation course does not a specialized translator make, it is clear that translation students benefit from specific training in technical translation. This specialized course offers a unique setting for the exploration of complex language, terminology, and documentary 
Guénette M.-F. (2021). Insights into technical translation course design. Current Trends in Translation Teaching and Learning E, 8, 196 - 234. https://doi.org/10.51287/cttle20217

research, as well as the analysis of job market requirements. In this article, I offered insights into course design, and provided an opportunity to discuss contemporary issues on the pedagogy of technical translation.

\section{ACKNOWLEDGEMENTS}

I am grateful for the funds extended by the Department of Languages, Linguistics and Translations at Université Laval which allowed me to hire a graduate student, Ewen Daigle Tretout, to research the topic prior to my course design. I also thank my peer reviewers for their attentive reading, and Wynne Miller and Valentine Patin for translating the majority of quoted text from French to English. 
Guénette M.-F. (2021). Insights into technical translation course design. Current Trends in Translation Teaching and Learning E, 8, 196 - 234. https://doi.org/10.51287/cttle20217

\section{REFERENCES}

Aerospace Industries Association of Canada. (2021).

Civil Aviation/Aviation civile. Aerospace

Industries Association of Canada/Association des industries aérospatiales du Canada. Accessed March 12, 2021. https://aiac.ca/fr/aviation-civile/

Bédard, C. (1986a). La traduction technique. Principes et pratique. Linguatech.

Bédard, C. (1987). Guide d'enseignement de la traduction technique. Linguatech.

Byrne, J. (2006). Technical Translation: Usability

Strategies for Translating Technical Documentation. Springer Netherlands.

Byrne, J. (2012). Scientific and Technical Translation Explained. A Nuts and Bolts Guide for Beginners. St Jerome Publishing.

Durieux, C. (1990/2010). Fondement didactique de la traduction technique. Maison du dictionnaire.

Durieux, C. (1990b). La recherche documentaire en traduction technique : conditions nécessaires et suffisantes. Meta, 35(4), 669-675. 
Guénette M.-F. (2021). Insights into technical translation course design. Current Trends in Translation Teaching and Learning E, 8, 196 - 234. https://doi.org/10.51287/cttle20217

European Commission. (2011). How to write clearly. Luxembourg : Publications Office of the European Union.

Government of Canada. (2021). About us - The Royal Canadian Air Force/À propos de nous L'Aviation royale canadienne. The Royal

Canadian Air Force. Accessed March 12, 2021. English website: https://forces.ca/en/about-us/air French website: https://forces.ca/fr/propos-denous/aviation

Government of Canada. (2021). Civil Aviation/Aviation civile. Transport Canada. Accessed March 12, 2021.

https://www.tc.gc.ca/fra/aviationcivile/menu.htm

Guénette, M.-F. (2021). Winter 2021 Syllabus TRD-7007 Traduction technique. Department of Languages, Linguistics and Translations, Université Laval.

International Civil Aviation Organization. (2021). Website of the International Civil Aviation Organization. Accessed March 12, 2021. https://www.icao.int/abouticao/Pages/default.aspx

Maillot, J. (1981). La traduction scientifique et technique. Technique et documentation. 
Guénette M.-F. (2021). Insights into technical translation course design. Current Trends in Translation Teaching and Learning E, 8, 196 - 234. https://doi.org/10.51287/cttle20217

Minacori, P. \& Veisblat, L. (2010). Translation and Technical Communication: Chicken or Egg? Meta, 55(4), 752-768.

N'Zafio, M. (1996). Qu'est-ce que "texte technique" veut dire? Technostyle, 13(1), 45-60.

Olohan, M. (2015). Scientific and Technical Translation. Routledge.

Public Works and Government Services of Canada PWGSC. (2021). "La langue claire et simple." Writing tools - Le guide du rédacteur. Produced by the Translation Bureau.

Senécal, A. (2012). Traduire pour l'aviation civile et militaire : Guide pratique et Lexique anglaisfrançais. Linguatech.

Senécal, A., Bédard, C., et al. (1987). Entre nous : Bulletin de traduction technique. Recueil complet (1978-1986). Linguatech.

Technitrad. (2021). What is technical translation? Accessed March 12, 2021. https://www.technitrad.com/what-is-technicaltranslation/ 
Guénette M.-F. (2021). Insights into technical translation course design. Current Trends in Translation Teaching and Learning E, 8, 196 - 234. https://doi.org/10.51287/cttle20217

Technitrad. (2020). Qu'est-ce que la traduction technique? Accessed May 27, 2020. https://www.technitrad.com/fr/qu-est-ce-que-latraduction-technique/

Tondji-Simen, R. (2005). Notions essentielles et enseignement de la traduction scientifique et technique. Meta, 50(4). https://doi.org/10.7202/019905ar

Zafio, M. N. (1996). L'adjectif « technique » : au-delà de la polysémie, l'histoire de l'évolution d'une attitude. TTR, 9(2), 193-212. https://doi.org/10.7202/037265ar 
Guénette M.-F. (2021). Insights into technical translation course design. Current Trends in Translation Teaching and Learning E, 8, 196 - 234. https://doi.org/10.51287/cttle20217

\section{APPENDIX 1. Reading list for graduate course on technical translation, numbered by week (Guénette 2021)}

1. Marquant, H. (2005). Formation à la traduction technique. META, 50(1), 129-136.

2. N'Zafio, M. (1996). Qu'est-ce que "texte technique" veut dire? Technostyle, 13(1), 45-60.

3. Senécal, A. (2012). La profession de traducteur technique. Traduire pour l'aviation civile et militaire: Guide pratique et Lexique anglaisfrançais. Montreal : Linguatech, pp. 3-11.

4. Durieux, C. (1990b). La recherche documentaire en traduction technique: conditions nécessaires et suffisantes. META, 35(4), 669-675.

5. Lagarde, L. \& Gile, D. (2011). Le traducteur professionnel face aux textes techniques et à la recherche documentaire. META, 56(1), 188-199.

6. Bédard, C. (1986b). Les lectures d'observation: la moisson du traducteur technique. META, 31(4), 420-427.

7. No class.

8. Minacori, P. \& Veisblat, L. (2010). Translation and Technical Communication: Chicken or Egg? META, 55(4), 752-768. 
Guénette M.-F. (2021). Insights into technical translation course design. Current Trends in Translation Teaching and Learning E, 8, 196 - 234. https://doi.org/10.51287/cttle20217

9. Ryan, R. (2011). Traduction technique : les langues contrôlées au service de l'ergonomie documentaire. ILCEA, 14 , https://ilcea.revues.org/1090.

10. Durieux, C. (1990a). Le foisonnement en traduction technique d'anglais en français. Meta, 35(1), 5560.

11. Durieux, C. (2000b). Traduction littéraire et traduction technique : même démarche. Revue des lettres et de traduction, 6, 13-25.

Minacori, P. (2005). Positionnement épistémologique de la traduction scientifique et technique, notion d'objectivité et implications pédagogiques. META, 50(4).

12. Dalügge-Momme, N. (2008). Aspects culturels de la traduction technique. Traduire, 217, p.5-13. http://journals.openedition.org/traduire/959

13. Byrne, J. (2006). Theory in technical translation. Technical Translation. Usability Strategies for Translating Technical Documentation. Dordrecht: Springer, 21-45. 